\title{
The Graphic Structure of Wayang Purwa Pandawa as a Reference for the Development of Contemporary Wayang Illustrations
}

\author{
Lintang Widyokusumo* Setiawan Sabana \\ *Faculty of Art and Design, Bandung Institute of Technology (FSRD-ITB) \\ J1. Ganesha 10, Bandung, West Java, Indonesia 40132
}

\begin{abstract}
Traditional shadow puppets are a real and symbolic form of art that appears as a spectacle, guidance, and order that can entertain and convey the teachings as a reference to life. Even UNESCO has proclaimed the arts of wayang purwa as "a Masterpiece of Oral and Intangible Heritage of Humanity." Despite its increasingly eroded by the times, it is undeniable that the protagonist of wayang puppets such as the Pandawa family has always been an inspiration in the development of the art world and the current design in the beauty of carving and graphic art that makes it a pre-modern art that is praiseworthy. According to the history of the origin of wayang, until now always undergoing an endless transformation of form. Since the time of Majapahit, the visual of wayang puppet that is still realistic until the era of the entry of Islam has been stilted and development until now. Shadow puppets Surakarta style is one type of wayang puppets are still often played and a reference to the form of graphics because of the beauty of carvings and graphic art. Shadow puppets are currently entering the postmodern period which is a postindustrial society that experienced a change in the assessment of aesthetics, especially for the younger generation. This phenomenon is a challenge for Pandawa Lima figures as a protagonist to remain present to become an idol and make it a choice of spectacle and guidance. This research uses qualitative research method through interview, literature study and field observation in Surakarta and Wonogiri area and supported by the postmodern theory of deconstruction. The results of this study show the graphic structure of Pandawa Lima collected can be a reference to the development of wayang in a new illustration work for the young generation of today who has the hybrid and liquid identity. In the end, experimental design of contemporary wayang illustration with a case study of Bima and Arjuna is expected to attract young generation.
\end{abstract}

Keywords: Wayang, Surakarta style, Pandawa, graphic structure, illustration

DOI: $10.7176 / \mathrm{ADS} / 78-06$

Publication date: November 30th 2019

\section{Introduction}

Wayang purwa is a legacy of high culture, the majesty of philosophy and beauty of carving and ornaments of wayang art has received world recognition. Even an international organization, UNESCO has proclaimed wayang purwa as "a Masterpiece of Oral and Intangible Heritage of Humanity" on November 7, 2003. Wayang is the shadow of our own life, from which we get a picture of experience in the world and the afterlife. Although the present presence has further undermined modern entertainment, the elegance of the wayang figures done with the visual beauty of graphics, wayang has brought inspiration to the artists and designers to make it the source of ideas of design works based on Indonesian culture (Javanese culture in particular). At the beginning of the creation of wayang is a replica of the Hindu temple reliefs that tend to be realistic. In fact, many temples contain reliefs of wayang stories such as Prambanan Temple near Yogyakarta, Penataran Temple near Blitar, or Jago Temple in Tumpang village, Malang Regency (Sony Kartika, 2012: 13). Relief of the temple became the inspiration of the king at that time to create a realistic wayang puppet in Majapahit era, but when entering the era of the influence of Islam to the land of Java, wayang experience a new aesthetic change tailored to the needs of the development of Islamic shari'a. The expertise of the religious leaders and kings in processing the wayang elements; produce wayang in a new form as a sign of the process of continuity of wayang tradition seen from the aspect of fine arts (Wiyoso, 1993: 41). Even up to now the wayang purwa always experience a relentless transformation.

The Mahabharata story in which there is a central character of the Pandawa as a protagonist is so famous and often appears in the plays of the shadow puppet. The name of the Pandawa is the five siblings of Pandu Dewanata who were born of two different mothers. Puntadewa, Bima, and Arjuna were born from Dewi Kunti while Nakula and Sadewa had Madrim Goddess mother. Central figures in the epic Mahabharata brings its inspiration for designers and artists to this day. Even in the Central Java area is still found a lot of people who idolize this Pandawa figure. Although each region in Indonesia such as Java and Bali has its standard in the form and variety of ornamental wayang, the art of wayang purwa carving has its own place in the world of puppetry art because of the beautiful detail of the decoration. 
The graphic structure of wayang purwa is often the reference of visual elements in some concept of development of illustration that can be applied in the works. As in the comics by the legendary artist R. A. Kosasih and also some other illustrators in Indonesia. This research tries to give an illustration of the way of graphic and fashion decoration of each Pandawa character in Surakarta style in detail, thus making it an inspiration to develop an illustration that can accommodate the taste of the present.

\section{Research Methodology}

This research uses qualitative research method in exploring visual data of wayang purwa graphic structure of Pandawa through literature study and field study covering observation and interview. Interviews and observations were made to the wayang artisans in the areas of the puppets of Kepuhsari and Surakarta villages. Research studies required in the design process of a design work takes time not least regarding searching the source of reference materials and understanding the meaning of a traditional masterpiece such as wayang. Detailed explanations of the physical form, fashion and accessories and their meanings can then be developed into supporting elements in the experimental design of a case study of illustrations Bima and Arjuna. In the process of developing the work of illustration using supporting methods on the concept of deepening and creation is a comparative method, and supported the theory of postmodern because drawings of contemporary puppets produced cannot be separated from the traditional art of wayang purwa Surakarta.

\section{Anatomical structure, fashion, and accessories of wayang purwa Surakarta}

Wayang purwa as previously mentioned is a native Indonesian art inspired by temple reliefs located in East and Central Java. When the proportion of human figures in the temple relief follows the standard dimensions of the human body and the realist, the anatomical structure of the shadow puppets is unique and completely different. The development of anatomical forms of wayang purwa undergoes a metamorphosis from the beginning created that was inspired from the reliefs at Penataran temple in East Java which also became the pattern of an anatomical figure of shadow puppet in Bali until today. On the island of Java in the form of wayang figures changed from pre-Majapahit era to the peak of the form of perfection in the reign of Mataram.

In this study, the researchers tried to peel the graphic structure of Pandawa puppets known as protagonists in the epic Mahabharata. Currently, a lot of development by artists and designers on Pandawa figures to become a new wayang work that follows the tastes of the present but sometimes so loose from the current wayang purwa graphic structure. In the category of puppets, the Pandawa are included in the group of Katongan puppets (figures of kings) such as Puntadewa, Arjuna, Nakula-Sadewa, but Bima belongs to the Jangkahan puppet category (foot stepping wide). Type of puppet Katongan average has a height of $50 \mathrm{~cm}$, and Jangkahan wayang has a height of about 75 to $80 \mathrm{~cm}$. The following illustration of figure 1 shows the high comparison of Katongan wayang compared to Jangkahan wayang.

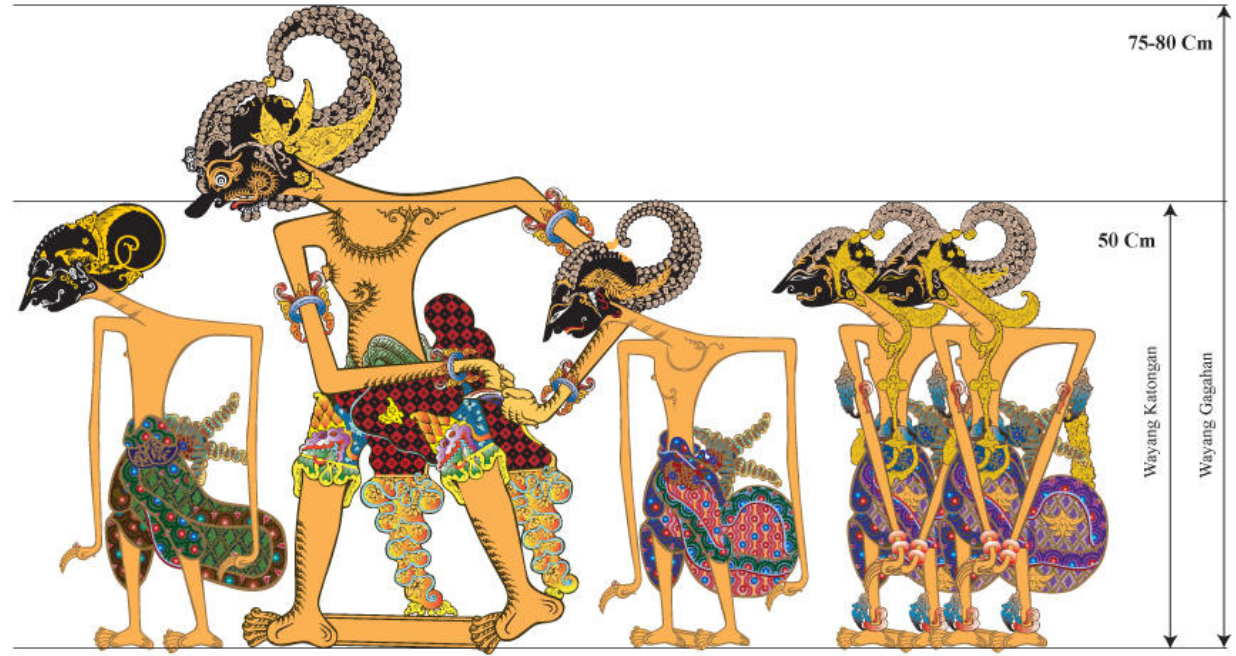

Figure 1. Differences in the high structure of puppet category Gagahan $(75-80 \mathrm{~cm})$ and Katongan $(50 \mathrm{~cm})$.

The high proportion of wayang purwa has a different concept with human anatomy in general. The average western human dimension has a height of seven to eight times the size of its head (1:7). Even the illustrators of American superhero figures Stan Lee gives his size for the ideal superhero height in his comic is eight and a half to nine times the size of a human head in general (1: 8.5-1: 9). 
For the proportion of Pandawa, it is seen that the amount of distortion compared to the ideal portion of the human, with the head and height ratio of the type of puppet Katongan 1:4 and the type of puppets Gagahan is 1: 3. The comparison can be seen in the illustration chart of figure 6 below; it appears that the proportion of the wayang looks awkward with the portions of heads that seem more massive than the body. Not only does the puppet's head look bigger, but the length of the hand also passes the knee of the foot compared to the proportion of the human hand whose range is limited to the hip.
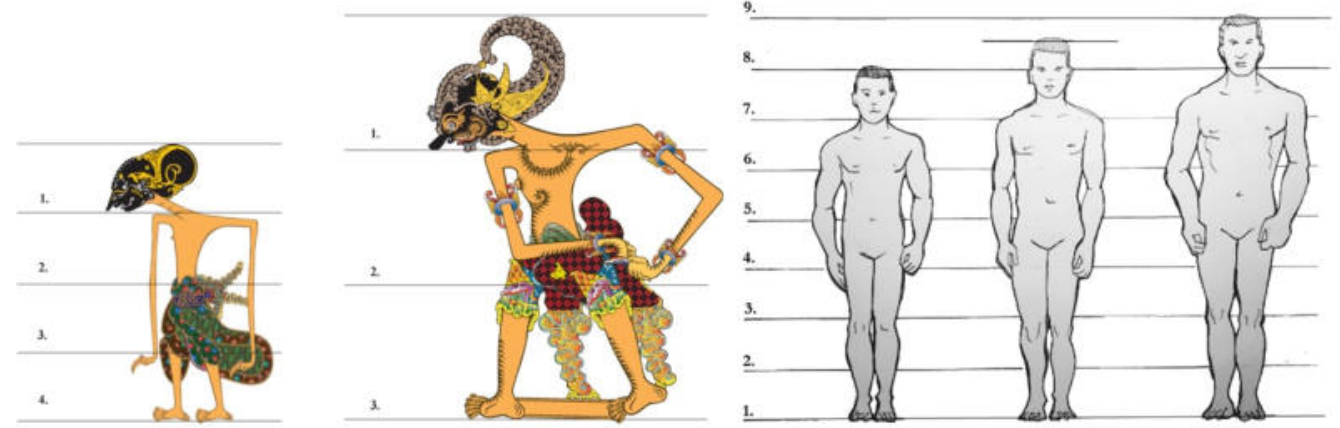

Figure 2. Proportion of Katongan puppet and gagahan puppet compared with the proportion of normal, ideal, superhero body of Stan Lee version.

In the history of the development of wayang purwa, did change quite far from the initial visual in the form of a realist. Since the entry of Islam in the era of Demak kingdom (1478-1546) and the kingdom of Pajang (1546-1586), there is a prohibition of the depiction of living things in realist. Then the wayang undergoes a change of stylized physical form towards the abstract way. The development of wayang formation continued until the time of Mataram kingdom (1586-1680) in this time puppets equipped with hand to move, and developing Kartasura-Surakarta style, Kedu-Yogyakarta style, Banyumasan style, Cirebonan style and various other areas (Haryanto 1991: 30).

In the stylized anatomical shaping of the wayang shapes, hands, legs, and legs are illustrated sideways with front-faced shoulders, with rear shoulder straps drawn longer toward the rear. With the position of the wayang's head visible from the side, allowing the shape of the face of the puppet to be seen from a distance with the elongation of the shape of the nose, mouth, and eyes. The shape of the neck extended forward, the shoulders are not symmetrical, and the legs are visualized sideways as if depicting a puppet figure as a dynamic and moving figure. Compared to the human anatomical figure that is entirely frontal front, it will appear silent, static sculpting. Aesthetic balance puppet anatomy visible when the head jutted forward then shape the hair bun, and other body jewelry be the perfect counterbalance. Like shape hair bun supit urang in figure Bima, Arjuna, Nakula and Sadewa and bun keling on Puntadewa figures.

Here is an infographic Pandawa puppet Surakarta style by displaying the physical traits of each character as well as decorative accessories clothing worn. In the Puntadewa character has the shape of grain eyes (form of grain) form of walimiring nose (small tip of the blade) closed mouth with a circular tip (keket). Clothing is worn by Puntadewa using dodot cloth (rounded ass shape) with a limar motif with knot fabric to store keris (manggaran) behind it. The hair is curled around the back (gelung keling) without crown (jamang). Accessories are worn on the ear using sumping waderan (shaped fish wader). His legs are visualized barefoot without accessories, illustrating his simplicity. Puntadewa body shape is slender-shaped with a downward face describes his patient and wise character. 


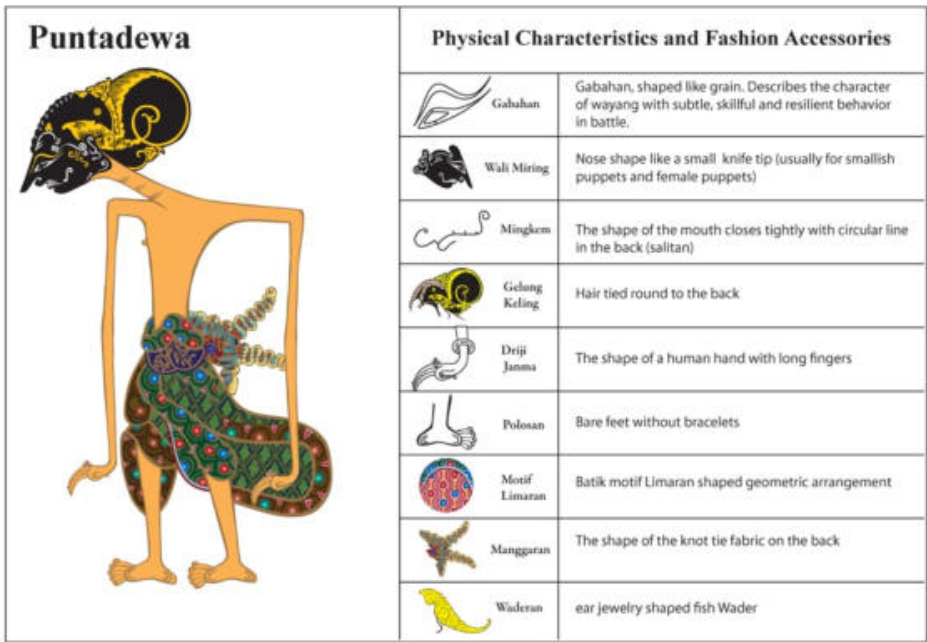

Figure 3. The physical characteristics and fashion accessories Puntadewa.

In Bima figure, has a more extensive anatomical structure in comparison with other brothers. By his character who is honest and firmly described big stocky and tall. Bima figures have the physical characteristics of the eye telengan (round eye) with a nose bentulan (like fruit bentul) with the mouth closed with keket at the end, as well as a hair bun like supit urang (claw shrimp) without crown (jamang). Especially for the character Bima has unique features such as large and pointy nails (pancanaka nails) and chandra kirana shoulder bracelets. In addition to the unique features of the nails, figures Bima also wear a motif of bang bintulu aji poleng cloth such as chessboard on the clothes he wore. To embellish the clothing Bima figure wearing ear ornaments sumping pudak sinumpet and trousers above the knee with a knot front and rear dodot cloth that hangs down. Bima legs are visualized barefoot without accessories.

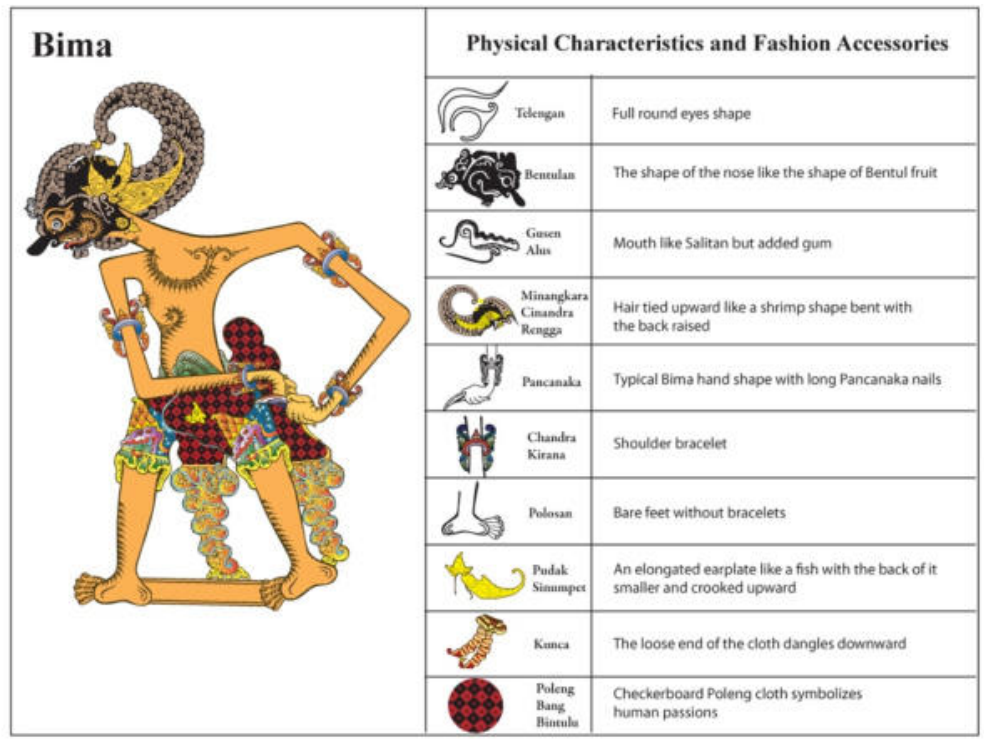

Figure 4. Bima's physical and fashion accessories.

The proportion of the body of the third Pandawa figure, Arjuna is similar to his eldest sibling Puntadewa, slender with the head down. Almost the same as the Puntadewa character, Arjuna is portrayed as a handsome and charms women with her archery skill. The physical characteristics of Arjuna have the shape of gabahan eyes, nose-shaped wali miring, the mouth closes with a keket at the end, and hair bun shaped supit urang without jamang. The ear decoration wearing the type of sumping waderan with the form of bokongan (butt rounded) dodot cloth patterned limar ketangi without sembulihan (cloth fold) and knot fabric (manggaran). Arjuna legs are visualized barefoot and without accessories (polosan). 


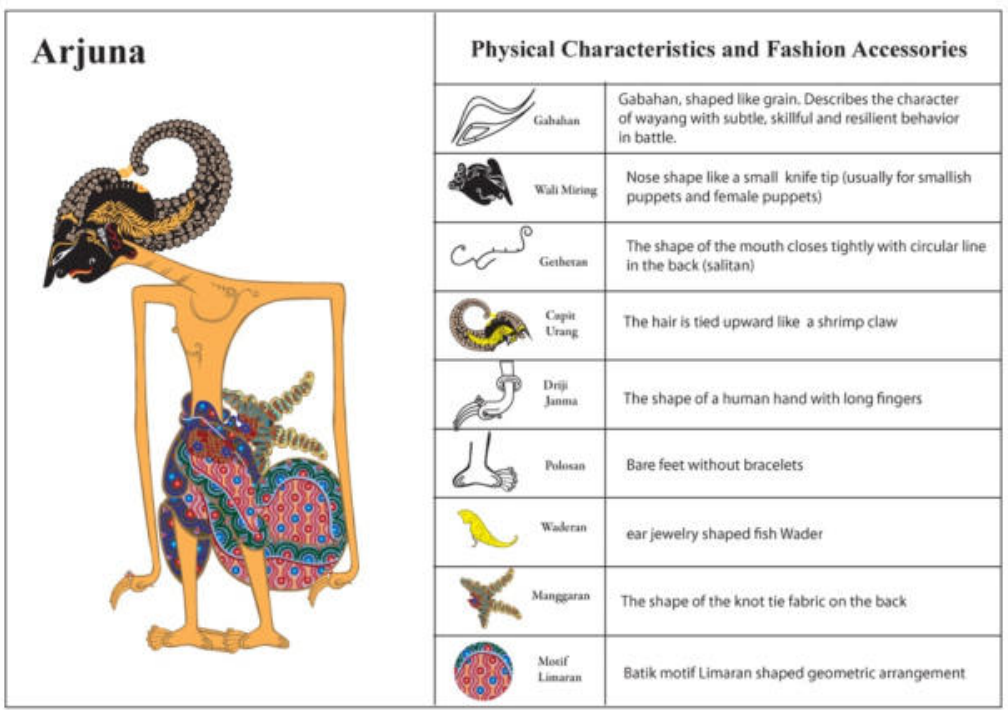

Figure 5. Arjuna's physical characteristics and fashion accessories.

The last Pandawa are the identical twins Nakula and Sadewa. In both, these figures are visualized precisely the same between each other on the physical appearance of the anatomy, clothing, and accessories they wear. The only difference is on the sunggar (front hair). Nakula and Sadewa have the same physical characteristics as their siblings Puntadewa and Arjuna that has gabahan eyes, nose wali miring and hair bun supit urang. Nakula and Sadewa's face looked straight ahead. In the look of clothing and accessories entirely different, visualized both use more accessories than the other siblings. Sumping ornaments use a kind of jackfruit flower shape (kluwih flower), long dangling necklaces, and naga memangsa leg bracelets. On their wrists wear a two-stacked kana bracelet and wear naga memangsa shoulder bracelet. Nakula and Sadewa wear a limar lapis layered fabric with larlaran (wing motif), on the back there is a folding cloth to store keris (manggaran) with a dangling jasmine flower.

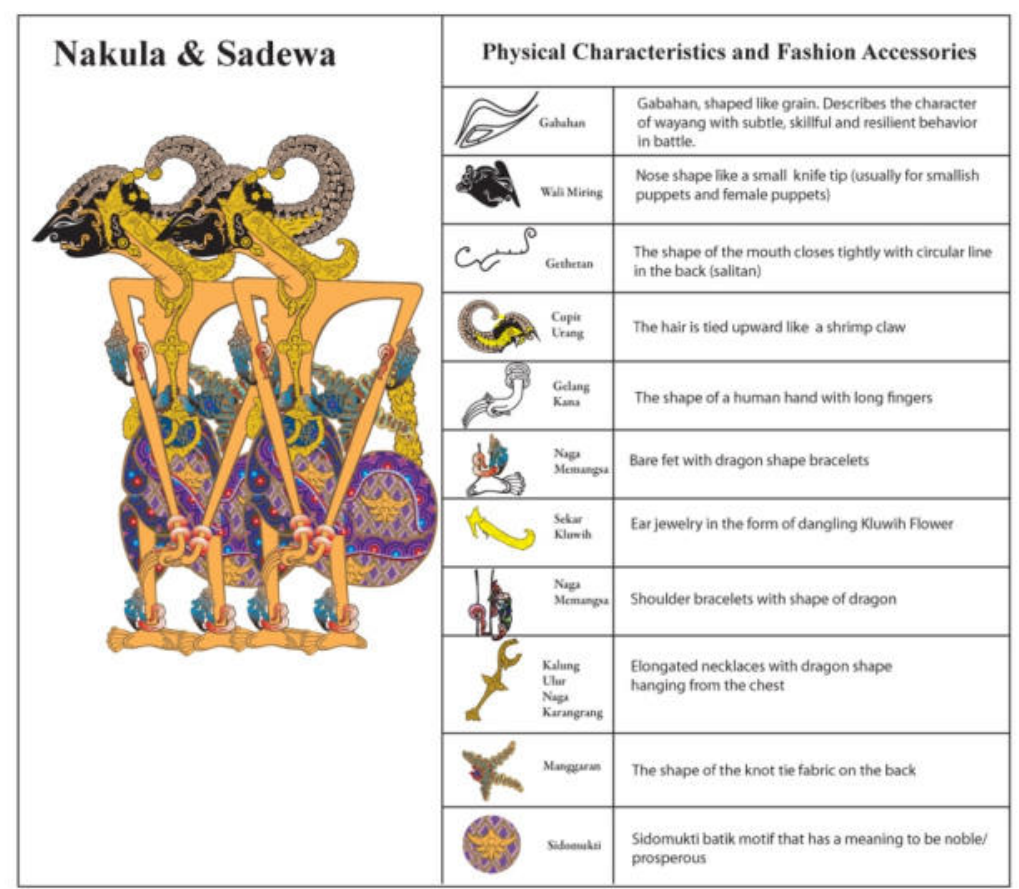

Figure 6. The physical and dressing characteristics of Nakula and Sadewa's accessories

\section{Experiments by contemporary wayang illustrations for children}

After describing the physical form of anatomy, fashion, and wayang accessories from the Pandawa, researchers are trying to design illustrations for children inspired by Pandawa puppets of Surakarta style. In this experiment, 
researchers decided to experiment with taking the case study of Bima and Arjuna because both figures are often a central figure in the wayang puppet play. These wayang illustrations are contemporary in style, in which the work is an idea of thought produced in the postmodern paradigm.

As Danto (1995: 10) through Saidi (2008: 18-19) says that the term contemporary art can be replaced with postmodern art, and the latter term can be considered more fundamental. The postmodern art tends to borrow the past for new, eclectic, theme-oriented contexts with a more free medium, work contextualization and local cultural awareness (Saidi, 2008: 21). In the concept of illustration designs, Bima and Arjuna wayang figures are various works inspired by wayang beber, wayang klitik and the style of today's cartoon illustrations. The composition of this illustrated work is inspired by wayang beber that developed from the era of the kingdom of Majapahit wherein a span of cloth sheets there is a detail scene illustration that can be told by the puppeteer.

The wayang beber show consists of several scenes of the story in which a series of whole story sequences illustrate each sheet. The stories are based on the Ramayana and Mahabharata stories and evolve into Panji's stories. Also, the concept of illustration style is also influenced by wayang klithik made of wood. The anatomical structure of wayang klithik which seemed stiff with simple ornament sculpture. These inspirations led to the illustration of Bima and Arjuna figures displaying rigid-looking illustrative anatomy by displaying a thick border by showing a more simple distillation decoration.

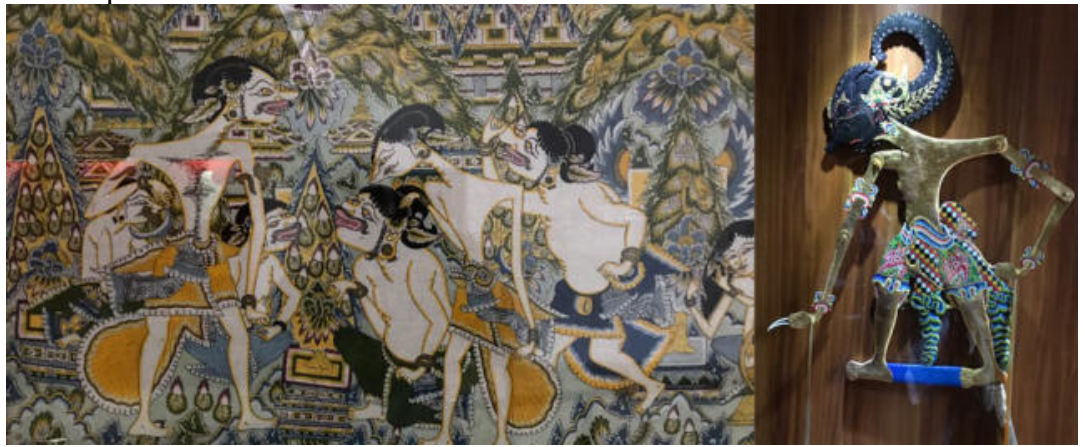

Figure 7. Wayang beber and wayang klitik

In the composition of this illustrated work tells the character of the figure of Bima from his birth, visualizes his supernatural powers and also displays the figure of his god role Dewa Ruci who lives in the ocean. At birth Bima wrapped in placenta so that the God sent a Sena elephant to break the placenta that eventually the elephant entered and fused in the body of Bima and increase his power. Propeller and wind illustrate that the figure of Bima is the incarnation of the wind god Batara Bayu.

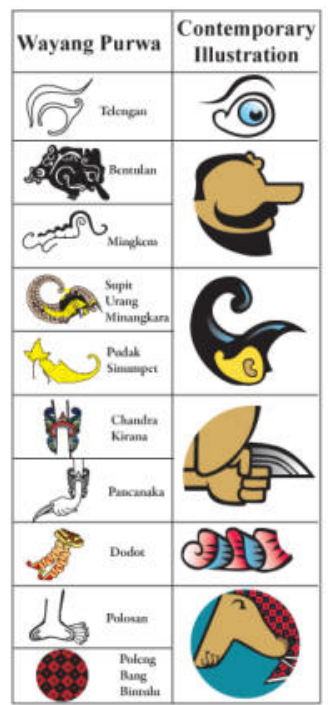

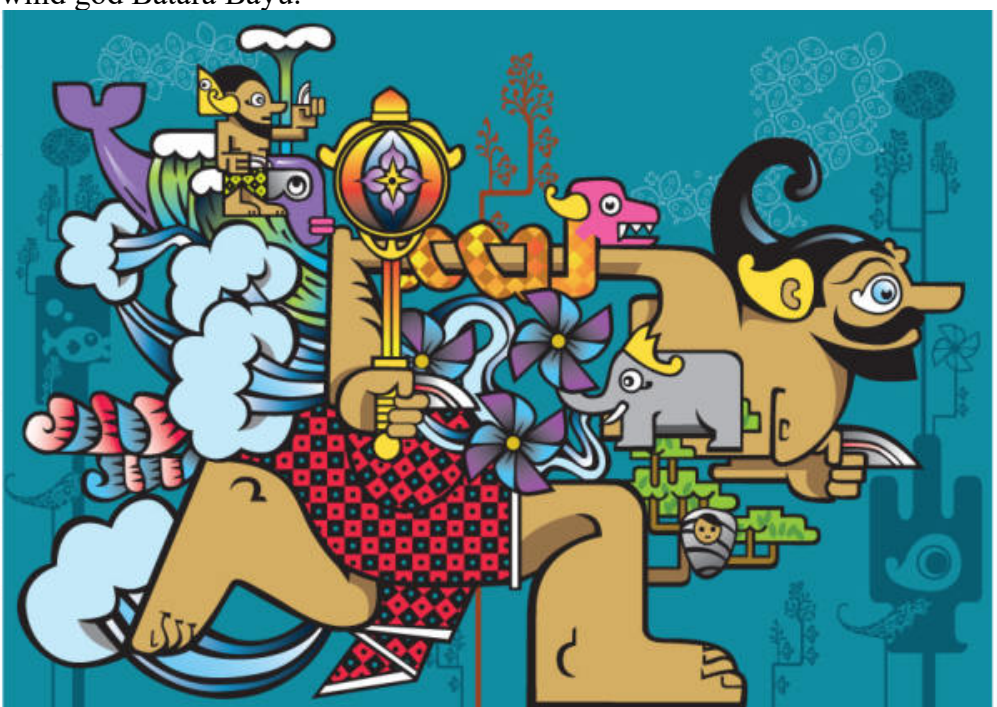

Figure 8. Bima Illustration Experiment

The next illustration composition depicts the character of Arjuna's third son of five siblings. In this composition is described that Arjuna is a wayang figure who is athletic and proficient in archery. Known to have the magic arrow Pasopati not only good at defeating his opponents but also described able to captivate the hearts of women illustrated here one of his wives who are also proficient archery Dewi Srikandi. Arjuna's handsome figure is depicted as capable of spreading charm for the opposite sex as the incarnation of the god of love Kamajaya. His patient and diligent nature in the search for knowledge is described that Arjuna diligently studied 
and fasted, not easily give up despite confronted obstacles and temptations. In the table to the left of the illustration is presented the transformation of the physical characteristics of anatomy and fashion accessories inspired by shadow puppet purwa distillation is simpler, with thick bold edges and using bright color composition as the purpose of illustration is for children.
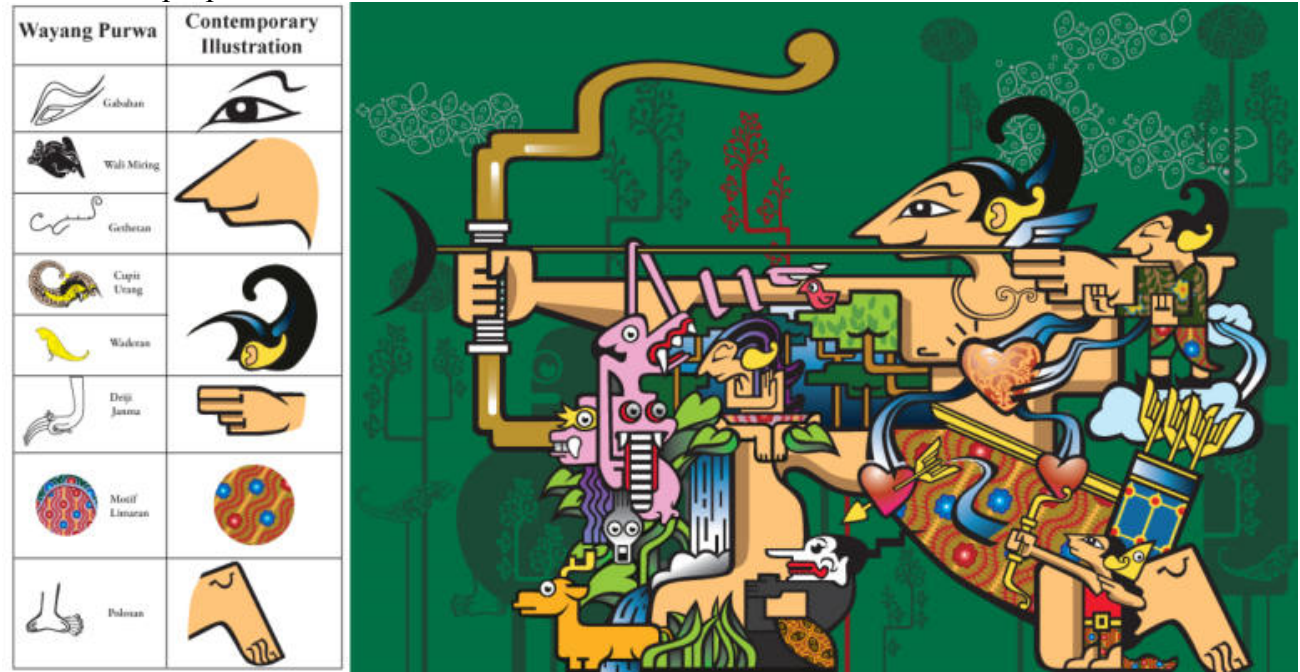

Figure 9. Arjuna Illustration Experiment

\section{Conclusion}

To have a strong identity in the current era of globalization requires an alternative search concept of art development. The cultural treasures especially the wayang purwa as the root of character will always be a source of inspiration for art and design. From the work of art that can give the stimulus of artistic creativity as a source of ideas and media of expression. Inspiration is not merely of Western art and design, but how to master modern conception as a medium of studying traditions as a discourse to welcome the new century (Dharsono, 2012: 172).

In the experimental design of illustrations that have been done, the graphic art of wayang purwa is still a standard reference. The physical characteristics of anatomy and fashion accessories play an essential role in the creation of a new style illustration as a medium of character recognition to the younger generation. The graphical structure of the Pandawa remains a reference to the development of puppets as a new illustration for today's young age with hybrid and liquid identities. By combining the wayang purwa graphic references and visual tastes of the present, it is hoped that the proposed works of the illustrations will be able to attract their attention without leaving too far the form of classical purwa puppets so that there is still a visual cultural attachment between them.

\section{References}

Dharsono, Sony Kartika. (2012). Seni Lukis Wayang. Surakarta: ISI Press. Haryanto, S. (1991). Seni Kriya Wayang Kulit. Jakarta: Pustaka Utama Graffiti. Lovejoy, Margot. (1997). Postmodern Currents. New Jersey: Prentice Hall. Rustopo. (2012). Seni Pewayangan Kita. Surakarta: ISI Press.

Saidi, Acep Iwan. (2008). Narasi Simbolik Seni Rupa Kontemporer Indonesia. Yogyakarta: Isaac Book. Yusuf Lubis, Akhyar. (2014). Postmodernisme Teori dan Metode. Jakarta: Rajawali Pers.

Wiyoso, Yodoseputro. (1993) Kesinambungan Tradisi dan Sumber Pengilhaman. Makalah Pengantar, Rupa Wayang dalam Seni Rupa Kontemporer Indonesia, Pameran Seni Rupa Kontemporer dalam Rangka Pekan Wayang Indonesia VI, 41 